\title{
Soft Skill Competencies, Hard Skill Competencies, and Intention to Become Entrepreneur of Vocational Graduates
}

\author{
Benedicta Prihatin Dwi Riyanti, Christine Winstinindah Sandroto, \\ M. Tri Warmiyati D.W \\ Universitas Katolik Atma Jaya, Jl. Jend. Sudirman, Jakarta Selatan 12930, DKI Jakarta, Indonesia
}

\section{A R T I C L}

entrepreneur,

competency,

intention

\section{A B S T R A C T}

This study aimed to determine the effect of soft skill competencies and hard skill competencies to the intention to become entrepreneur in the vocational school graduates. Hard skill entrepreneurial competencies are competencies that are needed to running business. Meanwhile for soft skill competencies are competencies related to aspects of personality and cognitive style. Population in this research is vocational graduates in Jakarta and Jogjakarta. The sampling technique used is incidental sampling. We used measuring instruments as follow: the intention to become entrepreneur of Shapero \& Sokol (in Riyanti, 2009). soft skill competencies of Spencer \& Spencer (1993) and hard skill competencies of Chou. Shen. Hsiou \& Chen. 2010). The regression analysis of the 258 respondents showed significant effect of soft skill competencies (initiative. self-confidence and assertiveness) to the intention to become entrepreneur in the vocational school graduates. There are significant effect hard skill competencies (human resources capability competency and production capability competency) to the intention to be entrepreneur. Based on the results. we suggested that the learning process should be more emphasis on direct practice so that more competencies can be formed on vocational school graduates.

SARI PATI

Penelitian ini bertujuan untuk mengetahui pengaruh kompetensi soft skill dan kompetensi hardskill terhadap intensi menjadi wirausaha pada siswa lulusan sekolah menengah kejuruan (SMK). Kompetensi hard skill kewirausahaan adalah kompetensi yang diperlukan untuk bisa menjalankan suatu usaha. Sementara kompetensi soft skill kewirausahaan adalah kompetensi yang berkaitan dengan aspek kepribadian dan gaya kognitif. Populasi dalam penelitian ini adalah lulusan SMK di Jakarta dan Jogjakarta. Teknik sampling yang digunakan adalah tehnik insidental sampling. Penelitian ini menggunakan tiga instrumen yaitu intensi mejadi wirausaha dari teori Shapero \& Sokol
Corresponding author:

benedictariyanti@yahoo.com 
(in Riyanti, 2009), kuesioner kompetensi soft skill dari teori Spencer \& Spencer (1993) dan kuesioner hard skill dari teori Chou, Shen, Hsiou \& Chen (2010). Hasil analisis regresi dari 258 responden menunjukkan bahwa ada pengaruh yang signifikan dari kompetensi soft skill (inisiatif, percaya diri dan assertive) terhadap intensi menjadi wirausaha pada lulusan Sekolah Menengah Kejuruan. Ada pengaruh yang signifikan kompetensi hard skill (kemampuan sumber daya manusia dan kemampuan produksi) terhadap intensi menjadi wirausaha pada lulusan SMK. Berdasarkan hasil ini, disarakankan agar proses belajar pada SMK harus lebih menekankan pada praktik langsung sehingga lebih banyak kompetensi bisa dibentuk pada lulusan siswa kejuruan.

(C) 2016 IRJBS, All rights reserved.

\section{INTRODUCTION}

Facing the ASEAN Economic Community (AEC) today, Indonesia needs to develop strategies to improve the competence of human resources. One of the human resources potential to be developed is students of Vocational High School (SMK). Therefore, it is not wrong if the Ministry of Education focused on vocational learning for the creation of new entrepreneurs that are reliable in its field (Paramita, 2014). Strengthening entrepreneurship in vocational school is strategic decision because if success, will be able to create a new entrepreneur to increase economic regions throughout Indonesia.

But in reality, $50 \%$ of vocational graduates directly hired, and only 1-2\% directly become entrepreneurs and success. While the rest contributed to the number of unemployed. And the number of unemployed graduates of vocational ranked highest compared to graduates of elementary school, junior high school, senior high school and university (Smk-penyumbangpengangguran, 2014).

This phenomenon is not only happening in Indonesia. Research conducted on 200 vocational school students of in Malaysia (Zakaria, Fadzilah \& Yusoff, 2011) showed that vocational students are less able to engage in entrepreneurial activities after leaving school because they do not have knowledge about entrepreneurship. Meanwhile other researchers in Malaysia found that vocational graduates are not much involved in the process of new business even though they have a good readiness to become entrepreneur (Othman, Hashim \& Zahari, 2010).

Entrepreneurship education is education that has always been done in various parts of the world. According to Black (in Holmgren \& Form 2005), the real purpose of entrepreneurship education is to encourage a change in attitude, in order to increase the number of students who see the business start-up as a career opportunity. In addition, Vesper (in Vyakarman, 2009) says that entrepreneurship educators can facilitate the process of entrepreneurship by creating awareness of entrepreneur opportunities. With the provision of education on entrepreneurship and awareness of the opportunities for entrepreneurship, then there is a greater likelihood of a person to perform self-employment. The same purpose was also held on entrepreneurship education in 
Indonesia, especially for creating the growth of new entrepreneurs.

According to Potter, entrepreneurship education is one of the key elements which can improve the attitude of entrepreneurs in a person (Potter, 2008). Because the development of entrepreneurship education is considered to make people aware of and interested in this career option, and make people more willing and able to open a new business.

Vyakarmam (2009) outlines the goals of entrepreneurship educational in three components. They are: 1). Personal development: entrepreneurship education is expected to build self-confidence, motivate progress, strengthening the entrepreneurial mindset, and fostering a desire to achieve and inspire the emergence of action; 2). Business Development: this includes the development of knowledge in terms of technical, financial, and skills that must be owned by entrepreneurs, including the expected business as well as the functional aspects of the curriculum; and 3). The development of entrepreneurial skills: entrepreneurship education should provide social skills training, networking, ability to solve problems creatively, skill to see an opportunity, manual dexterity, interview, presentations, leadership skills within the group, skills work together in the community, dealing with the bureaucracy, as well as the norms of the local culture and how all it affects the business. Based on the opinion of Vyakarnam above, ideal entrepreneurial education includes aspects of knowledge (theory), skills (practice), and the development of the personality of the prospective entrepreneurs.

According to Spencer \& Spencer (1993), three aspects of entrepreneur education built competencies. Spencer \& Spencer defined competence as an intrinsic attribute of an individual that can be used to predict the behavior and their performance in the workplace. Thus competence is the capacity that there is someone who can make a person able to fulfill what is required by the job within an organization so that the organization is able to achieve the expected results.

Based on the scope of work and responsibility, experts develop entrepreneurial competencies. Callisten (2015) explained that there were six soft skills, namely public speaking, time management, relationship building, leadership, negotiation and empathy.

Spencer \& Spencer (1993) described thirteen basic dimension in entrepreneurship. Thirteenth dimension is becoming a characteristic that is generally owned by people who are entrepreneurial. The thirteen dimensions are as follows: (1) initiative, (2) see and take advantage of opportunities, (3) perseverance, (4) searching for information, (5) high performance focus, (6) commitment to job , (7) orientation on efficiency, (8) systematicly planning, (9) problem solving (10) self-confidence, (11) persuasive skills, (12) influencing strategies, (12) assertive.

Another expert Chou, Shen, Hsiao \& Chen (2010) developed the ten competencies in business students, namely (1) entrepreneurial spirit, (2) marketing competence, (3) economic competence, (4) financial competence, (5) accounting competence, (6) management competence, (7) globalization competence, (8) law competence, (9) enterprise resources planning competence, (10) information technology competence.

According to Zhang \& Zhang (2013), psychological characteristics of entrepreneur of college students include five aspects: entrepreneurial capacity, entrepreneurial belief, entrepreneurial consciousness, entrepreneurial motivation, and entrepreneurial determination.

Meanwhile Fitriati \& Hermiati (2010) found that each program in administration sciences has 
differentskilland different characteristics concering entrepreneurial skill and chareacteristic. But they said that student in all program of administration science need entrepreneur education.

Based on competences above, entrepreneurial competence can be divided into hard skill and soft skill competencies. Hard skill entrepreneurial competencies include ten technical competencies (Chou, Shen, Hsiao \& Chen, 2010). Meanwhile for soft skill competencies are competencies related to aspects of personality. Researchers will refer to the competence of entrepreneurship by Spencer \& Spencer (1993).

In this study, we will only use five of the ten hard skills competencies proposed by Chou, Shen, and Chen Hsiao (2010). It was did because new students in vocational high school have received knowledge that related to those five competences. This five competences are: (1) The ability of human resources management, which have competence in the field of manage people, and develop worker. The ability of human resource management is the ability to manage available resources, divide the tasks based on ability and ensure optimal work processes and best performance can be achieved; (2) Marketing capability, which have competence in finding a suitable market, identify customers and maintain the viability of the company. He must know how to find specific market opportunities, e.g. customers and special prices that are not managed competitors; (3) Production Capability. Production capability is the ability in processing goods, from raw materials into finished goods. This capability includes the technical capabilities in the production process; (4) Management capability is the ability to manage existing resources, administration and work so that productivity can be maximized the business; and (5) Financial competence, which have competence in the field of finance, arrange the purchase, sale, accounting, and profit / loss. He must know how to get the funds and use them.
In this study, for soft skill competencies, we have thirteen soft skill competencies acoording to Spencer \& Spencer (1993). It is divided in two categories. First, soft skill of personality and second, soft skill of cognitive style. Soft skill of personality is a characteristic of someone who permanent and influence behavior. While soft skills of cognitive style are characteristic of a person when faced with a problem, he will fix the problem in certain ways. Competencies of soft skills of personality consist of initiative, perseverance, performance, commitment and self-confident. Soft skills of cognitive style is seeking information, efficiency, systematic planning, problem solving, persuasive skills, influencing others and assertiveness.

In addition to competence, education is one of the factors that may affect intentions to become entrepreneurs because the intention itself is based on the perceptions and will of a person in achieving his behavior in the future (Zhang \& Zhang, 2013). In addition, education related to a person's cognitive social process in which the assumption in the process also involves a person's perception.

According to Fishbein \& Ajzen (1975 in Riyanti, 2009), the intention is defined as a person's position in the dimensions of subjective probability that involve a relationship between himself and some action. Therefore, the intention of behaving lead to the person's subjective probability that he will do real behavior. Krueger, Reilly \& Carsrud (in Riyanti 2009) defines intention as "the degree of commitment toward some future targets behavior". Intention is the degree of one's commitment to the target behavior in the future. Intention direct behavior and make people adopt plans that aim in the future will be possible.

Ajzen (1991) developed a theory of psychology called behavior plan. According to the Theory of Planned Behavior, a person can act on the intention or the intention is only if he has control 
of his behavior. This theory not only emphasizes the rationality of human behavior, but also on the belief that the target behavior is under the control consciousness of the individual's or a behavior not only depends on the intentions of a person, but also on other factors that are not under the control of individuals such as the availability of resources and opportunities to display such behavior. Hence the Ajzen expand his theory by emphasizing the role of later referred to as Perceived Behavioral Control.

Based on theory of planed behavior, intention is a function of three determinants, the first who is persona (attitude toward behavior), the second reflect the social influence (subjective norm) and the third relates to the issue of control (perceived behavioral control) (Ajzen, 2005). Other experts, Shapero \& Sokol (in Riyanti, 2009) adapted the theory of Planned Behavior of Fishbein \& Ajzen and applies specifically in the entrepreneurial world. According to Shapero \& Sokol intentions are influenced by three dimensions:

1. Perceived desirability: perceived personal desirability showed preference someone who sees the creation of new businesses as something attractive and desirable. This bias grows from a see of the consequences of personal entrepreneurial experience (good or bad), and the level of support from the environment (family, friends, relatives, colleagues, etc.). This variable reflects individual affection towards entrepreneurship.

2. Perceived feasibility: this element indicates the degree of confidence in which a person sees himself has the ability to collect those resources (human, social, financial) to establish new enterprises.

3. Propensity to act: propensity to act showed a boost in a person to behave and their intensity varies greatly for each individual. The determinant is not only having a direct effect to the intention, but also have an indirect effect.
Krueger (2000) test this hypothesis with a model of entrepreneurial intention from Shapero. Krueger found that previous entrepreneurial experience is the antecedent of perception, whether it's the perceived desirability and the perceived feasibility. Furthermore, previous entrepreneurial experience can be seen from two sides of the quantity and quality. Quantity relates to the previous rules of thumb in a family business, the involvement of family members in the business, or participation in a new business startup. This quantity is then referred to as the breadth of experience. While in terms of quality is a person's perception of the experience, whether good or bad. In terms of quality is finally also called positiveness of experience.

Vocational curriculum was developed to improve human resources that are competent and skilled in their field that is able to compete in the era of globalization. Education is directed to create a society with a lifestyle of modern industry and commerce.

Vocational education divides subjects into groups according concentration basic subject areas of expertise (15 credits), a group of subject basic skills program (7 credits) and group membership package subjects (24 credits). Overall there were 48 credits in vocational education. Entrepreneurial subject delivered in grade $1,2,3$, and 4 , respectively 2 credits. 48 credits are designed to produce graduates with the competencies spiritual attitudes, social attitudes core competencies, core competencies and core competency skills knowledge. This means that the overall curriculum in vocational graduates who have the competence to form hard skill and soft skill competencies. Hard skill competence is the competence relating to technical competence according to the field of science. Such as production processes competence, marketing competence, human resource management competence. The soft skills competence is: self-confidence, discipline, 
independence, cooperation, honesty, fair, creative and innovative, and never give up. As said by Fayolle \& DeGeorge (2006) that education plays in fostering entrepreneurial intentions to become entrepreneurs.

When referring to the curriculum designed for vocational students, after graduation vocational students should have sufficient knowledge and have interest/desire to become entrepreneurs.

Based on the phenomena above. researchers wanted to know:

1. From forming intention's dimensions. which dimensions most influential toward intentions to become entrepreneur in vocational graduates.

2. How does the soft skill competence toward the intention to become entrepreneur in vocational graduates.

3. How does the hard skill competence toward the intention to become entrepreneur in vocational school graduates.

The researchers selected this theme because it will provide data about the factors that influence the intention to become entrepreneur in the vocational school graduates.

The research purpose are:

1. Gain an understanding which dimensions of the forming dimensions that the most influential toward the intention to become entrepreneur in vocational graduates in Jakarta and Jogjakarta.

2. Determine the effect of soft skill competencies to the intention to become entrepreneur in vocational graduates in Jakarta and Jogjakarta.

3. Determine the effect of hard skill competencies to the intention to become entrepreneur in vocational graduates in Jakarta and Jogjakarta.

\section{METHODS}

Population and Sampling

This study population is vocational students who have just graduated in vocational Jakarta and Jogjakarta. Jogjakarta and Jakarta have been selected for reasons of convenience only. The sampling technique used was accidental/ convenient sampling. This technique is used because researchers do not know with certainty the number of population accurately.

\section{Research Instruments}

This study used three questionnaires. Questionnaires intention to become entrepreneur according to Shapero \& Sokol (in Riyanti, 2009), the competence of soft skill by Spencer \& Spencer (1993), instrument hard skill competency refers to the opinion of Chou, Shen, and Chen Hsiao (2010).

\section{Operational Definition}

Operational definition for each variable are:

1. Intention to be entrepreneurs according to Shapero \& Sokol: a person's tendency to choose a profession as an entrepreneur, seed from three dimensions of perceived desirability, perceived feasibility, propensity to act (Shapero \& Sokol in Riyanti, 2009)

2. Soft skills competency (Spencer \& Spencer, 1993) is a competency that consists of 13 dimensions, namely (1) initiative, (2) see and take advantage of opportunities, (3) perseverance, (4) searching for information, (5) focus on the high level of performance, (6) commitment to job, (7) orientation on efficiency, (8) systematic planning, (9) problem solving, (10) confidence, (11) the persuasive ability, (12) influencing strategies, (12) assertiveness.

3. Hard skill competency (Chou, Shen, Hsiao \& Chen, 2010) is a competence that consists of 1) the ability of human resource management, 2) marketing capability, 3) production capability, 4) management capability, 5) financial capability.

\section{RESULTS AND DISCUSSION}

Research data analysis was conducted using SPSS aplication for windows 22.0 . 
Table 1. Measurement intentions to become entrepreneur (Shapero \& Sokol) - Sample of items, Validity \& Reliability

\begin{tabular}{lclll}
\hline Dimension & $\begin{array}{l}\text { Number of } \\
\text { valid item }\end{array}$ & Sample items & Validity & Reliability \\
\hline $\begin{array}{l}\text { Perceive } \\
\text { desireability }\end{array}$ & 8 & $\begin{array}{l}\text { I am confident of being able to } \\
\text { become entrepreneur }\end{array}$ & $0.480-0.764$ & 0.846 \\
\hline $\begin{array}{l}\text { Perceived } \\
\text { feasibility }\end{array}$ & 6 & $\begin{array}{l}\text { A career as an entrepreneur is a } \\
\text { difficult thing for me }\end{array}$ & $0.539-0.734$ & 0.856 \\
\hline Propensity to act & 3 & $\begin{array}{l}\text { I would do anything to become } \\
\text { entrepreneur }\end{array}$ & $0.521-0.585$ & 0.562 \\
\hline Total valid items & 17 & & \\
\hline
\end{tabular}

\section{Validity and Reliability Measurement}

\section{Validity (item analysis)}

Validity test of the items in this study is testing the construct validity. We used internal consistency in testing the construct validity. The formula used is the Pearson Product Moment Correlation.

\section{Reliability Test}

Testing the reliability using the formula coefficient Cronbach alpha. it because this measure retrieval of data is only done once. in addition to the range of scores that exist in measuring tools that researchers use non-dichotomous (items that have a range of scores is wide) (Anastasi \& Urbina. 1997).

\section{Validity and Reliability Test Results}

The results of statistical calculations for the validity of the intention to become entrepreneur' instrument indicates that: for perceived desireability dimention. from fifteen items only eight items are valid. For perceived feasibility dimension. of a thirteen item six are valid. For propensity to act dimension. of ten items only three valid.

Table 1 showed the validity and reliability test results for intentions to become entrepreneur.

The measuring instrument soft competency

Soft skill competency instrument originally consisted of 101 items divided into 13 dimensions.
The result of the calculation of validity and reliability showed only 2 invalid item. That item is one item from the dimention of high performance and one item from dimensional of efficiency.

Table 2 showed the validity and reliability test results for soft skill competencies.

Hard skill competencies instrument consists of 37 items. Having tested the validity and reliability. all items are valid and reliable. Table 3 showed the validity and reliability test results for hard skill competencies.

\section{Data Analysis Techniques}

Data will be analyzed with descriptive statistics and multivariate statistical techniques regression analysis. Of the 258 respondents, 108 respondents (41.9\%) stated choose to starting a business after graduation.

\section{Description of Respondents}

Of the 274 questionnaires distributed, only 258 questionnaires were complete and fit to use. So for further analysis we use total number of respondents are 258 respondents.

From table 4 . it showed that $50.80 \%$ of respondents are male and $49.20 \%$ are female.

From table 5, respondent who lived in Jogjakarta $58.90 \%$ and the rest $41.1 \%$ lived in Jakarta. 
Table 2. Soft skill Competencies Measurement Tool (Spencer \& Spencer) - Sample of items, Validity \& Reliability

\begin{tabular}{|c|c|c|c|c|}
\hline Dimension & $\begin{array}{l}\text { Number of } \\
\text { valid items }\end{array}$ & Sample items & Validity & Reliability \\
\hline Initiative & 6 & $\begin{array}{l}\text { I was able to change things for the } \\
\text { better }\end{array}$ & $0.383-0.657$ & 0.765 \\
\hline $\begin{array}{l}\text { Seeing } \\
\text { Opportunities }\end{array}$ & 8 & $\begin{array}{l}\text { I was able to look for business } \\
\text { opportunities }\end{array}$ & $0.582-0.831$ & 0.928 \\
\hline Perseverance & 8 & $\begin{array}{l}\text { I was able to focus on a task to } \\
\text { completion }\end{array}$ & $0.438-0.640$ & 0.819 \\
\hline $\begin{array}{l}\text { Searching for } \\
\text { information }\end{array}$ & 8 & I was able to ask something in detail & $0.539-0.711$ & 0.874 \\
\hline $\begin{array}{l}\text { High performance } \\
\text { Focus }\end{array}$ & 7 & $\begin{array}{l}\text { I was able to be disciplined with } \\
\text { time }\end{array}$ & $0.495-0.687$ & 0.687 \\
\hline $\begin{array}{l}\text { Commitment to } \\
\text { job }\end{array}$ & 8 & $\begin{array}{l}\text { I was able to survive the tough task } \\
\text { that became my responsibility }\end{array}$ & $0.264-0.621$ & 0.626 \\
\hline Efficiency & 7 & $\begin{array}{l}\text { I was able to act quickly and } \\
\text { precisely }\end{array}$ & $0.472-0.621$ & 0.626 \\
\hline $\begin{array}{l}\text { Systematic } \\
\text { planning }\end{array}$ & 8 & $\begin{array}{l}\text { I was able to think logically and } \\
\text { systematically }\end{array}$ & $0.440-0.687$ & 0.826 \\
\hline Problem solving & 9 & $\begin{array}{l}\text { I was able to find innovative } \\
\text { solutions to a problem }\end{array}$ & $0.610-0.766$ & 0.901 \\
\hline Self-confident & 8 & $\begin{array}{l}\text { I am able to influence others in my } \\
\text { way }\end{array}$ & $0.456-0.734$ & 0.866 \\
\hline Persuasive skill & 6 & I was able to convince others & $0.310-0.721$ & 0.853 \\
\hline $\begin{array}{l}\text { Strategy } \\
\text { influencing }\end{array}$ & 7 & $\begin{array}{l}\text { I was able to approach the } \\
\text { important people who can support } \\
\text { my efforts }\end{array}$ & $0.534-0.705$ & 0.861 \\
\hline Assertive & 7 & $\begin{array}{l}\text { I was able to hold my strong basic } \\
\text { principle }\end{array}$ & $0.307-0.476$ & 0.591 \\
\hline Total of valid items & & 97 & & \\
\hline
\end{tabular}

Table 3. Hard Skill Competency Measurement tool - Sample of item, Validity and Reliability

\begin{tabular}{lclcr}
\hline Dimension & $\begin{array}{c}\text { Number Of } \\
\text { Valid Items }\end{array}$ & Sample of item & Validity & Reliability \\
\hline HR Capability & 6 & I was able to manage resources & $0.529-0.721$ & 0.869 \\
\hline Marketing Capability & 8 & $\begin{array}{l}\text { I was able to determine the } \\
\text { option market }\end{array}$ & $0.632-0.752$ & 0.898 \\
\hline Production capability & 8 & $\begin{array}{l}\text { I was able to make a variety of } \\
\text { different products }\end{array}$ & $0.709-0.784$ & 0.933 \\
\hline $\begin{array}{l}\text { Management } \\
\text { capability }\end{array}$ & 8 & $\begin{array}{l}\text { I was able to set the salaries and } \\
\text { bonuses }\end{array}$ & $0.650-0.808$ & 0.927 \\
\hline Financial capability & 7 & $\begin{array}{l}\text { I was able to calculate the cost } \\
\text { of goods sold }\end{array}$ & $0.473-0.761$ & 0.927 \\
\hline Total & 37 & & & \\
\hline
\end{tabular}


Table 4. Gender of the respondents

\begin{tabular}{lll}
\hline Gender & Total & $\%$ \\
\hline Male & 131 & $50.80 \%$ \\
\hline Female & 127 & $49.20 \%$ \\
\hline Total & 258 & $100.00 \%$ \\
\hline
\end{tabular}

Table 5. City of Vocational Education Respondents

\begin{tabular}{lll}
\hline City & Total & $\%$ \\
\hline Yogyakarta & 152 & $58.9 \%$ \\
\hline Jakarta & 106 & $41.1 \%$ \\
\hline Total & 258 & $100.00 \%$ \\
\hline
\end{tabular}

\section{Analysis}

Table 6 showed the results of descriptive statistic calculation for each dimensions of variables.

\section{Soft Skill Competencies (Personality) and Intention to Become Entrepreneur}

After processed by SPSS V.25.0, we found that simultantneously soft skill competencies personality variable, with dimension initiative, perseverance, focus on performance, commitment to job, and self-confidence gave a significant effect to intention to become entrepreneur $(\mathrm{F}=9.370 ; \mathrm{p}=0.000)$. Taken together into five variables contributed $15.7 \%(\mathrm{R}$ Square $=.157)$ to the intention to become entrepreneur. For each dimension of soft skill competencies of personality to intention to become entrepreneur the results showed in table 7.

With alpha or p-value 0.05 so the results are as follows, the initiative and self-confident gave a significant effect on the intention to become entrepreneur in vocational graduates (sig<0.05),

Table 6. Calculation of Descriptive Statistic Variables

\begin{tabular}{lllllr}
\hline & N & Minimum & Maximum & Mean & Std. Deviation \\
\hline Desire & 258 & 12.00 & 42.00 & 31.9845 & 7.24446 \\
Feasible & 258 & 22.00 & 77.00 & 58.9535 & 13.28957 \\
Prospncti & 258 & 34.00 & 119.00 & 90.9380 & 20.52473 \\
Intensshapr & 258 & 68.00 & 238.00 & 181.8760 & 41.04946 \\
Initiative & 258 & 6.00 & 42.00 & 34.0349 & 4.98273 \\
Opportunity & 258 & 8.00 & 56.00 & 46.2287 & 7.51691 \\
Perseverance & 258 & 8.00 & 56.00 & 43.4690 & 6.95798 \\
S.information & 258 & 8.00 & 56.00 & 46.8488 & 6.47627 \\
Performance & 258 & 7.00 & 49.00 & 39.8256 & 5.35115 \\
Commitment & 258 & 8.00 & 56.00 & 47.9109 & 6.22501 \\
Efficiency & 258 & 21.00 & 49.00 & 40.5465 & 5.43871 \\
Systematic Plan & 258 & 20.00 & 56.00 & 46.5543 & 6.23276 \\
Problem solving & 258 & 32.00 & 63.00 & 52.9767 & 6.39244 \\
Self-confident & 258 & 26.00 & 56.00 & 45.4341 & 6.44745 \\
Persuasif skill & 258 & 21.00 & 42.00 & 34.7403 & 4.69108 \\
Influencing & 258 & 27.00 & 56.00 & 46.0116 & 5.74726 \\
Assertiveness & 258 & 27.00 & 56.00 & 47.3527 & 5.58448 \\
HR Capability & 258 & 22.00 & 49.00 & 40.9884 & 5.04646 \\
Marketing & 258 & 26.00 & 49.00 & 41.3372 & 5.18741 \\
Production & 258 & 27.00 & 63.00 & 53.2248 & 7.00832 \\
Management & 258 & 24.00 & 56.00 & 47.2636 & 6.44766 \\
Financial & 258 & 37.00 & 84.00 & 71.2326 & 8.91596 \\
Valid N (listwise) & 258 & & & & \\
\hline
\end{tabular}


Table 7. Calculation of beta and t-test

\begin{tabular}{lllllll}
\hline \multirow{2}{*}{ Model } & \multicolumn{2}{c}{ Unstandardized Coefficients } & \multicolumn{2}{c}{$\begin{array}{l}\text { Standardized } \\
\text { Coefficients }\end{array}$} & $\mathrm{t}$ & \multirow{2}{*}{ Sig. } \\
\cline { 3 - 5 } & & $\mathrm{B}$ & Std. Error & Beta & & \\
\hline \multirow{2}{*}{1} & (Constant) & 63.391 & 22.407 & & 2.829 & .005 \\
& initiative & 1.575 & .624 & .191 & 2.524 & .012 \\
& perseverance & .216 & .474 & .037 & .457 & .648 \\
& performance & -1.189 & .619 & -.155 & -1.920 & .056 \\
& commitment & .442 & .550 & .067 & .802 & .423 \\
& Self-confident & 1.797 & .440 & .282 & 4.085 & .000 \\
\hline
\end{tabular}

a Dependent variable: intention to become entrepreneur

but perseverance, high performance focus, and commitment to job did not give a significant effect on the intention to become entrepreneur in vocational graduates (sig $>0.05$ ).

\section{Soft Skill Competency (Cognitive Style) and Intentions to Become Entrepreneur}

Simultaneously, soft skill competencies of cognitive style variable, they are: seeking information, efficiency, systematic planning, problem solving, persuasive skill, influencing others and assertiveness, gave a significant effect on the intention to become entrepreneur ( $\mathrm{F}=$ 5.133; $\mathrm{p}=0.000)$. Seven variables simultaneously contributed by $12.6 \%$ ( $\mathrm{R}$ Square $=.126$ ) to the intention to become entrepreneur. For each dimension of soft skill competencies of cognitive style to intention to become entrepreneur the results showed in table 8 .

From table 8, with alpha or p-value 0.05 , we found that from all seven variables soft skill competency of cognitive style, only assertiveness dimension that significantly influence to the intention to become entrepreneur in vocational graduates (sig $<0.05$ ). Thus assertiveness the only real variable exert significant influence on the intention to become entrepreneur in the vocational school graduates.

Table 8. Calculation of beta and test $\mathrm{t}$

\begin{tabular}{|c|c|c|c|c|c|c|}
\hline \multicolumn{2}{|c|}{ Model } & \multicolumn{2}{|c|}{ Unstandardized Coefficients } & \multirow{2}{*}{$\begin{array}{l}\text { Standardized } \\
\text { Coefficients } \\
\text { Beta }\end{array}$} & \multirow[t]{2}{*}{$\mathrm{t}$} & \multirow[t]{2}{*}{ Sig. } \\
\hline & & $\mathrm{B}$ & Std. Error & & & \\
\hline \multirow[t]{8}{*}{1} & (Constant) & 12.168 & 3.601 & & 3.379 & .001 \\
\hline & s.information & -.003 & .075 & -.004 & -.046 & .963 \\
\hline & efficiency & -.059 & .112 & -.051 & -.529 & .597 \\
\hline & systematic plan & .119 & .119 & .117 & .998 & .319 \\
\hline & Problem solving & .026 & .115 & .027 & .227 & .820 \\
\hline & Persuasive skill & .003 & .124 & .002 & .026 & .980 \\
\hline & influencing & .056 & .103 & .051 & .539 & .590 \\
\hline & assertiveness & .274 & .111 & .243 & 2.464 & .014 \\
\hline
\end{tabular}

a Dependent variable: intention to become entrepreneur 


\section{Competence Hard Skill and Intention to Become Entrepreneur}

Simultaneously hard skill competencies variable, they are: HR capability, marketing capability, production capability, management capability and financial capability gave a significant effect to the intention to become entrepreneur (F $=10.763 ; \mathrm{p}=0.000)$. Taken together into five variables contributed $17.6 \%$ (R Square $=.176$ ) to the intention to become entrepreneur. The results showed in table 9.

From table 9, we found that only HR capability competency and production capability competency gave a significant effect on the intention to become entrepreneur in vocational graduates $(\mathrm{sig}<0.05)$, but marketing capability competency, management capability competency and financial competency did not give a significant effect on the intention to become entrepreneur in vocational graduates (sig $>0.05)$.

\section{Discussion}

The results of this study indicate that soft skill competencies of personality that influence the intention to become entrepreneur in vocational graduates are initiative and self-confidence. This shows that vocational students with initiative and self-confidence that will be interested in choosing entrepreneurhip as a profession. This finding is consistent with the theory of the emergence of entrepreneurhip as a process.
Therefore, to become entrepreneur is taken time and long process. Only those who have the initiative will be able to surpass the stages up to the establishment of a business. Likewise, selfconfidence is the basic capital must be owned by vocational students. With these two personalities, then his or her intention to choose entrepreneur as a profession can survive through processes of maturation to really become entrepreneur.

Meanwhile for soft skills competencies of cognitive style, assertive competency is the only one of seven cognitive style competencies that exerts significant influence on the intentions of vocational school graduates to be entrepreneurs. This finding seems to indicate the outcome of the process for vocational education; perseverance is honed and exposed a lot in entrepreneur life. Beside for other competencies such as the seeing opportunities or persuasive skills competencies have no impact on intentions to become entrepreneur because these competencies are rare or seldom seen in teaching and learning process. Things to do relating to the entrepreneur business and training may not emphasize the seeing opportunities or persuasive skills competencies.

Hard skill competencies that have a significant effect on the intention to become entrepreneur's competency is HR capability and production capability competencies. If referred to the core curriculum in vocational education, especially on

Table 9. Calculation of beta and test $\mathrm{t}$

\begin{tabular}{|c|c|c|c|c|c|c|}
\hline \multirow{2}{*}{\multicolumn{2}{|c|}{ Model }} & \multicolumn{2}{|c|}{$\begin{array}{c}\text { Unstandardized } \\
\text { Coefficients }\end{array}$} & \multirow{2}{*}{$\begin{array}{c}\text { Standardized } \\
\text { Coefficients }\end{array}$} & \multirow[t]{2}{*}{$\mathrm{t}$} & \multirow[t]{2}{*}{ Sig. } \\
\hline & & $\mathrm{B}$ & Std. Error & & & \\
\hline \multirow[t]{6}{*}{1} & (Constant) & 9.221 & 3.380 & & 2.728 & .007 \\
\hline & HR capability & .226 & .095 & .181 & 2.373 & .018 \\
\hline & Marketing cap. & -.108 & .118 & -.089 & -.915 & .361 \\
\hline & Production cap. & .297 & .120 & .330 & 2.473 & .014 \\
\hline & Mgment cap. & -.073 & .125 & -.075 & -.582 & .561 \\
\hline & Financial cap & .081 & .078 & .115 & 1.040 & .300 \\
\hline
\end{tabular}

a Dependent variable: intention to become entrepreneur 
the subjects of entrepreneurship, it seems that HR capability and production capability competencies are two competencies that most sharpened when the student take internship or when students asked to make a business activity as a practical task.

\section{MANAGERIAL IMPLICATIONS}

The result of this study showed that soft skills competencies of personality, initiative and selfconfidence showed a significant effect on the intention to become entrepreneur. There for learning process that forms the students believe in their own abilities need to be emphasized. For example, with the duties and tasks independently designed by student learners.

Soft skill competencies of cognitive style, it is assertiveness also gave a significant effect on the intention to become entrepreneurs. This assertiveness competency can be sharpened by giving students assignments that require them to make their own decisions.

Entrepreneurship in vocational education has showed the Human Resources capability competency and production competency as hard skill competencies gave a significant effect on the intention to become entrepreneur. Both of these competencies need to be improved. To add other competencies, entrepreneurship in vocational education should be more willing to explore marketing capability competency, management capability competency and financial capability competency by implementing the teaching and learning process that emphasizes practice rather than theory or written report.

Entrepreneurship education program is the educational programs that have been implemented for long in various parts of the world. For Indonesia, entrepreneurship education, especially in vocational high schools is still relatively new. Entrepreneurship education curriculum implemented still needs to be studied and developed. One that needs to be emphasized in entrepreneurship education is to realize that being an entrepreneur is a process. Because it is important to enter the processes of business establishments in entrepreneurship education curriculum. This means that entrepreneurship education is sequential, for example, entrepreneurial education starting with how to make a business idea, how to make a business plan, how to realize business ideas into reality and how to manage the business. The education process should be done with more emphasis on practice rather than theory.

According to Black (in Holmgren \& Form 2005), the real purpose of entrepreneurship education is to encourage a change in attitude, in order to increase the number of students who see the business start-up as a career opportunity allows. In addition Vesper (in Holmgren \& Form 2005) says that entrepreneurship educators can facilitate the process of entrepreneurship by creating awareness of entrepreneurship opportunities. With the provision of education on entrepreneurship and awareness of entrepreneurship opportunities, then there is a greater likelihood of a person to perform self-employment. The same purpose was also held on entrepreneurship education in Indonesia, especially to increase the growth of new entrepreneurs.

\section{CONCLUSION}

This study shows that intentions to become entrepreneurs in the vocational graduates are influenced by the competencies of soft skills and hard skills. The findings provide understanding for all of us that the educational process should facilitate the forming of competence. To achieve this, the process of learning in vocational school should increase direct practice so that the results of learning not only to having knowledge but also generating competence.

Another conclusion in this research is study entrepreneurial subject already shaped soft skills competency initiative, self-confident, and assertive. 
We expect that study entrepreneurial subject can increase innovative and relationship ability so vocational graduates will be able to expand the network and discover new ideas in business.

Meanwhile, for hard skill competencies, the entrepreneurial learning process in vocational schools need to be improved so that the graduates not only have of human resources management competencies and production competencies but also marketing competencies and financial competencies.

\section{REFEREN C ES}

Anastasi, A. \& Urbina, S. (1997). Psychological testing (7th ed.). New Jersey: Prentice Hall.

Ajzen, I. (1991). The theory of planned behavior. Organizational behavior and human decision processes, 50, $179-211$.

Ajzen, I. Fishbein, M. (2005). Theory-based behavior change intervention: comments on hobbis and sutton. Journal of health psychology, 10 (1), 27-31.

Callisen, L. (2015). 6 Soft Skills for Entrepreneurs: A Guide to Success. www.startupnation.com/articles/6-soft-skillsentrepreneurs-guide-success/oct 12, 2015.

Chou, C.M.; Shen, C.H; Hsiao, H.C, Chen, S.C. (2010). A Study on Constructing Entreprenurial competence indicators for business departement students of vocational and technical colleges in Taiwan. World Transactions on Engineering and Technology Education, 8 (3), 316-319.

Douglas , E.J., \& Shepherd, D.A. (1997). Entrepreneurial Atiitudes and Intentions of Career Decision Makers. Working Paper at Kellog Graduate School of Management, Northwestern University. Download 31-10-2013 from website: http://www. researchgate.net/publication/2436596_Entrepreneurial_Attitudes_and_Intentions_of_Career_Decision_Makers

Fayolle, A. \& DeGeorge, J.M. (2006). Attitudes, Intention and Behavior: New Approaches to Evaluating Entrepreneurship Education. Issues and Newness. Edward Elger Publishing Limited.

Fitriati R. \& Hermiatu T. (2010). Entrepreneurial skills and characteristics analysis on the graduates of Departement of Administrative Sciences, FISIP Universitas Indonesia. Journal of Administrative Science \& Organization, $262-275$.

Hamidi, D.Y., Wennberg, K., Berglund,H. (2008). Creativity in entrepreneurship education. Journal of Small Business and Enterprise Development, 15 (2), 304-320.

Krueger, N, Jr.; Reilly, M.; Carsrud, A., (2000). Competing models of entrepreneurial intention. Journal of Business Venturing, 15 (2), 177-194.

Kumar,R. (2005). Research Methodology: A Step by Step Guide for Beginners. London:Sage Publication Inc.

Linan, F \& Juan C.R. \& Jose, M.R.C, (2011). Factors affecting entrepreneurial intention levels: a role for education. Entrepreneur Management Journal , 7,195-218.

Mitchelmore, \& Rowley, J. (2010). Entrepreneurial Competencies: A Literature Resee and Development Agenda. Article in International Journal of Entrepreneurial Behaviour \& Research 16(2):92-111. Website: Http://www. Researchgate.net/.../235277302_entrepreneurial competee.

Othman, A.K., Hashim, M.A., Zahari, (2010). The Influence of Entrepreneurship Education and Experience on Students' entrepreneurship spirit: The Moderating Effect of Internal Locus of Control. Advances in Business Research International Journal.

Paramita, R.P. (2014). SMK Penyumbang Pengangguran Terbesar. http://beritagar.id/artikel/berita/smk-penyumbangpengangguran terbesar.

Rasmussen, S.A. \&Sorheim, R. (2006). Action-based entrepreneurship education. Technovation, 26 (2), $186-94$.

Riyanti,B.P.D., (2009). Kewirausahaan Bagi Mahasiswa. Jakarta: Unika Atmajaya. Scarborough, N., Wilson, D.L., Zimmerer, T. (2011). Essentials of Entrepreneurship and Small Business Management. Prentice-Hall. 
Shermon, G. (2004). Competency Based HRM: A Strategic Resource for Competency Mapping, Assessment and Development Centres. Tata McGraw-Hill

Shepherd, D.A., \&Douglas, E.J., (1997). Is management education developing, or killing, the entrepreneurial spirit. Paper presented at he 1997 USASBE Annual National Conference Entrepreneurship: The engine of global economic development, San Fransisco, California.

Spencer, L.M.\& Spencer, S.M. (1993). Competence at work. Canada: John Wiley \& Sons, Inc.

Vyakarnam, S. (2009). Driving force of entrepreneurship education. In Educating the new wave of entrepreneurs: Unlocking entrepreneurial capabilities to meet the global challenges of 21st century; Edited by C. Volkmann, K.E., Wilson, S. Mariotti, D., Rabuzzi, S., Vyarkarman and A Sepulveda. Cologny, Switzerland: Work economy forum.

Zakaria, S, Fadzilah W, Yusoff, W. (2011). Entrepreneurship Education in Malaysia: Nurturing Entrepreneurial Interest Among Students. Journal of Modern Accounting and Auditing, ISSN 1548-6583, 7 (6), 615-620.

Zhang, H. \& Zhang, Y. (2013). Psychological characteristics of Entrepreneurship of college students in China. Scientific research Psychology, 4 (3), Published online March 2013 in SciRes. Website: http://www/scrip.org/journal/psych 